Journal of Humanities, Social and Management Sciences (JHSMS)

eISSN: 2788-4791 (online)

https://doi.org/10.47264/idea.jhsms/2.1.6

Vol. 2, No. 1 (January-June 2021), 63-71

https:// www.ideapublishers.org/index.php/jhsms

Review Article

\title{
The role of political opposition: A pre-requisite for democracy
}

\author{
Arif Khan* | Saiful Islam | Muhammad Alam \\ Department of Political Science, Faculty of Social Sciences, University of Buner, Sowari, Pakistan. \\ *Corresponding Author Email: arif@ubuner.edu.pk
}

Published: August 24, 2021

\begin{abstract}
No doubt for a democracy to be triumphant, multi-party system or, at least two-party systems is obligatory. A country with one party system lacks observant and efficient opposition. There is every chance for the incumbent party to become autocratic and domineering. One party system is most of the times susceptible to transform into dictatorship. Most of the times where there is one party system, the opposition is stifled and trampled, and the dictatorship of the single party is established. Germany during Hitler's rule and Italy during Mussoloni rule are the cases in point. One cannot imagine of a democratic set up without a healthy and watchful opposition. For the success of any parliamentary democracy, an effective opposition is must to carry out its functions courageously and effectively. The paper analyses the rights, responsibilities and obligations of opposition in a democratic system. The techniques adopted by the researcher for data collection include a detailed survey of the available literature covering different aspects of the topic. Internationally reputed authors and experts have been quoted. It is for the government to allow the opposition to fulfil their functions, which indicates a sign of democratic maturity on the part of government. The opposition has to focus on democratic functions and if it fails to do so, it will be a sign of dysfunctional democracy.
\end{abstract}

Keywords: democracy, political party, party system, government, democratic government, opposition, opposition party, parliament, parliamentary system.

\section{How to Cite:}

Khan, A., Islam, S., \& Alam, M. (2021). The role of political opposition: A pre-requisite for democracy. Journal of Humanities, Social and Management Sciences (JHSMS), 2(1), 63-71. https://doi.org/10.47264/idea.jhsms/2.1.6

\section{Publisher's Note:}

IDEA PUBLISHERS (IDEA Journals Group) stands neutral regarding jurisdictional claims in the published maps and institutional affiliations.

\section{Copyright:}

(C) 2021 The Author(s), published by IDEA PUBLISHERS (IDEA Journals Group)

This is an Open Access article published under the Creative Commons Attribution-NonCommercial 4.0 International License (http://creativecommons.org/licenses/by-nc/4.0/) 


\section{Introduction}

The opposition is an unavoidable part of a democracy. In a parliamentary system, the political party voted to power, forms the government and remains in office for the mandated term. The house is usually a two wings house. On the right side of the speaker, the ruling party members are seated whereas the left side is the opposition's abode (Bagbin et al., 2015). According to Schapiro, opposition is "an organized political group with the aims to oust the government in power and to replace it by one of its own choosing" (Schapiro, 1967). In an open democracy, there is always room for choice all the way up to the selection of government. This means that divergent opinions are provided an opportunity to be heard in the legislature. It also refers to the views of those parliamentarians who are not part of the government and are opposed to the policies of the incumbent government. Simply, the elected representatives of the people, either belonging to the government benches or the opposition must be provided an opportunity to express their opinion, present alternative policy options and take part in the parliamentary discussion and debates. Such a faction in the parliament that does not belong to government is called the opposition. ${ }^{1}$

The political parties with less number of seats sit in the assembly as opposition and present their own view, give suggestions to the government and sometime challenge the government policies if they are against the interest of the common people. In a democracy, the opposition parties are free to work and draw the attention and support of the masses and convey a signal to the incumbent government and present itself as the second choice to replace the incumbent party/parties (Akhtar, 2013).

The opposition may be of different types according to the nature of political system. Simply, opposition means the political party or parties that do not have majority in the parliament and always ready to disagree with and criticize government actions and policies that are not seeking common interests (European conference of presidents of parliaments, 2014). The term opposition refers to those political parties whose members seek support of citizens not as individual candidates but as an organized and disciplined political party and as an alternative government ( $53^{\text {rd }}$ Commonwealth parliamentary conference, 2007).

Parliament is the place of debate and transaction of the people's business by their elected representatives. Thus, opposition in democracy is necessary for representing people and for settling differences with the government. Discussions and dissent are the part of democracy and opposition becomes inevitable for the system. Strong and effective democracy needs an equally strong and effective opposition. The strength of opposition in a parliament shows the quality of democracy (53 ${ }^{\text {rd }}$ Commonwealth Parliamentary Conference, 2007). In fact, opposition is an inevitable component of a democratic system.

The role of opposition has been analyzed under democratic theory. According to Democratic Theory the principle of legitimate political opposition is one of the most fundamental components of liberal democracy. Democracy is an ideology of opposition as much as it is one of government (Bagbin et al., 2015). Real democracy is impossible without opposition. One cannot think of a democratic set up without a healthy and vigilant opposition. For the success of any parliamentary democracy, an effective opposition is must to perform its functions fearlessly and effectively. The opposition works for the rights of the people. History teaches us that freedom dies when criticism ends. 


\section{Methods and materials}

This is an a descriptive, analytical and exploratory research study and the techniques adopted by the researcher for data collection include a detailed survey of the available literature covering different aspects of the topic. Qualitative research method is applied for collecting and analyzing the data. Most of the data was collected by using secondary sources such as journals, research articles and books. Both print and electronic media was used to cover different aspects of the topic and to reach a conceptual understanding. Different materials written by authors of standing were followed and the author benefitted from the articles published in reputed journals.

\section{Importance of opposition in a democratic system}

The opposition works for the rights of the people. History teaches us that freedom dies when criticism ends. The opposition checks the incumbent party's despotism. Where there are elements in the form of informed critics for good means, a healthy criticism, which can hold the government responsible and answerable for its actions then the government, is attentive to its duties. The continuous situation at loggerhead with the opposition keeps the government in action all the time around as it cannot afford to be lacking and careless. Excellence could only be achieved in strict checks and watchful eyes of opposition. Mutual consensus allows a bill to become law, and it is sanctioned from opposition too. The opposition combs through the bill for any discrepancies and it is aftereffects in the long run. If opposition is absent, then the ruling party can act despotically ${ }^{2}$ and the vested interest could overpower the public interest in a busied environment.

\section{Rights and responsibilities of opposition}

The opposition in any democratic set-up enjoys the right to operate freely and promote democratic values. Laws or actions that hinder or put fetters on opposition are not only harmful for opposition but also have adverse effects on the promotion of democracy. Some of the guidelines mentioned in the Council of Europe Parliamentary Assembly Resolution 1601 (2008), ${ }^{3}$ are enumerated below:

- Opposition members must have freedom of expression, freedom of opinion and to freely express their views on matters under discussion in the house.

- Members of the opposition in parliament shall enjoy the right to information. They must have free and equal access to information in the same manner as the ruling party members.

- Opposition members have the right to inform the citizens. They also have the right of access to different sources of information such as television channels, internet sites etc. The opposition members shall be privileged to debate, discuss and scrutinize the policies, decisions and actions of the government. It also enjoys the right to ask oral or written questions from the members of the government. In the same manner, they have the right to receive replies to their questions. They have the right to open question time and members of the opposition shall be privileged to ask more questions than members of the government. The opposition can hold the incumbent government accountable by tabling a motion of censure or no confidence. The right to ask for a discussion and debate regarding an urgent and important issue and it should be granted if the required number of members demand so. The right to request for setting up a committee of inquiry, a fact- 
finding mission or parliamentary mission of information. The right to ask for a special session of parliament to discuss some matters of urgency. It should be granted if the required number of parliamentarians so demand. Opposition shall be allotted sufficient speaking time. Under certain circumstances, equal speaking time to government and opposition members should also be ensured.

- The right to take part in the management of parliamentary work. The right of access to different posts likes vice-president and other posts of responsibility. The composition of any governing body in parliament shall respect the principle of proportional representation and opposition shall be given its due share.

- It includes the right to initiate legislation and table bills and motion on various legislative matters, the right to propose and present amendments in laws, the right to speak in all legislative debates. Similarly, they have the right to vote, the right to present procedural motions for change in the adopted agenda and the right to refer a report back to the concerned House Committee.

- The chairmanship of various permanent and standing committees inside the parliament shall be allotted to the parliamentary parties on the basis of proportional representation. Opposition be allowed to head at least one permanent committee. Chairmanship of the main monitoring and oversight committees ${ }^{4}$ should be allowed to a member from the opposition. All the committees, permanent or standing shall be composed of various political parties in accordance with their strength in the parliament. In the committees, the members of opposition shall have the right to speak and right to vote. The right to be designated as a rapporteur on the basis of proportional representation.

- The right to ask for reviewing the constitutionality of the adopted laws and refer the matter to constitutional court or other legal body prior to their adoption. The right of access to Audit Court and asking for its opinion on financial matters.

Along with all the above-mentioned rights, the opposition shall participate in political decisions. Opposition shall also be consulted before any decision to dissolve the parliament. In the same fashion, every democratic government and parliament in the world provides opportunity for dissent and tolerates opposition to their policies and acts. Inside the parliament, the government under the rules provides representation to the opposition member on committees and other policy-making bodies. Even opposition led various important committees in the parliament like the Public Account Committee (PAC) in Pakistan, which is a legislative organ of the national assembly of Pakistan. The committee "ensures the transparency and accountability in the Ministries/Divisions and in the Public-Sector Organizations. The Committee thoroughly examines the Report of the Auditor General of Pakistan and calls the representatives from the respective Ministries and Departments to investigate and enquire about the issues of Financial Irregularities."

\section{Role and obligations of opposition}

Both ruling and opposition parties are central to the working of democracy. That is why both ruling, and opposition parties share the basic democratic values such as the freedom of speech, rule of law and equal protection under the law. In fact, the opposition is, "government-in thewaiting." The opposition should have the right to express their views, to dissent or criticize the incumbent government, if democracy has to be promoted. Besides, the opposition parties need to have confidence that they have a chance to campaign and present themselves before the electorates for seeking their votes through free, fair and regular elections (Kiiza, 2005). Shortly, 
if democracy is to be promoted the principle of 'majority rule, must be accompanied by minority right i.e., accommodation of dissenting views.

Political pluralism and democracy cannot be separated. Government's acceptance of opposition, protest and the existence of an institutional representation for the political opposition are the preconditions for the effective working of democratic institutions. French philosopher and political scientist Raymond Aron, holds the view that democracy is a system "in which a peaceful rivalry for the acquisition of power exists constitutionally" (European conference of presidents of parliaments, 2014). The role of opposition in the proper functioning of liberal democracy is universally acknowledged (Bagbin et al., 2015).

In democracies, if the government represents the majority, the opposition also represent a section of the population. Dissent is pertinent to democracies because it helps to understand and make sense of what is going around. Progress without dissent and its acceptance is impossible in a democratic society. Though some-times it causes heavy damage to the system which takes a lot of time to recover however, the worst case would be a so-called democracy where dissent is silenced. When dissent is often replaced by fear (Kamila, 2021). Imposing majoritarian and one-sided policies and silencing dissent opinions sometimes create prolong violence in societies (Ozair \& Khan, 2017). The opposition in the parliament and in the society as citizens are tolerated in a democratic society. Neglecting oppositions and their silencing creates polarized societies where dialogues and creative discussions are forbidden. People living in such societies create "one-dimensional view" of the world they live in.

Democracy places emphasis on an orderly pattern of relationship between the ruling and opposition parties, which is to be characterized by consensus and participation. Although the opposition parties do not hold executive positions, yet they do exercise a check on the ruling party/coalition. Democracy allows the opposition to criticize the government and put forward alternative policy options. On the one hand, if opposition is required to grant recognition to the authority of government, on the other hand, it is also expected to exercise a check on the government. This is because a flourishing democracy always needs an active and effective opposition. In a democratic system, all the political parties whether from ruling or opposition side develop an atmosphere of trust, tolerance and understanding and resolve their differences peacefully. The rulers govern the country on the consent of governed. The opposition parties also recognize the right of the majority party to rule and make decisions but, at the same time, the ruling party also respects the opposition's right to dissent (Teshome, 2009). For determining effectiveness of democracy in its real sense, it is important to examine the role of opposition as a yardstick. Not only the ruling party but the opposition parties too have an important role to play. The role of opposition parties is not critical only, but it should also be constructive (Akhtar, 2013). The effective role of opposition is more important in parliamentary system because there is every possibility of combining the executive and legislative powers, which may enable the executive to acquire preponderance over all other state institutions. In such a situation, the presence of an active and vigilant opposition and regular alteration of government are important for having a check on the executive branch of government.

The opposition parties struggle for safeguarding the rights and the interests of the people. With this view, they criticize the government in case the latter ignores them. They resort to protestation in the House and at the public level. It counts very much for raising the level of political consciousness among the people. However, sometime just for the sake of opposition, 
the opposition criticizes the right policy of the government, which is harmful for democracy (Kumari, n.d.).

Members of the opposition parties are also included in various committees connected to the respective ministries. All procedures and dealings of the government associated with the respective ministries are talked about and settled by them. The opposition plays a considerable role in it through making recommendations (Kumari, n.d.). The responsible opposition parties play an important role in the promotion of democracy as is evident from the following headings:

\subsection{Opposition as the voice of the voiceless}

The opposition in a democratic set up monitors the day-to-day activities and performance of the incumbent government and keeps the citizens informed. Both the party in power and the one in opposition are the agents of citizens (Przeworski et al., 1999). The opposition plays a special role both inside and outside the Parliament by voicing concern over the grievances of various groups and other interests that are not represented in the parliament (Bagbin et al., 2015). It makes certain that the opinions of the opposition are given full coverage, particularly when the issue at hand is of immense national importance. Thus, the opposition becomes the voice of the voiceless section of society. By doing so, they build the confidence of the public and assures them that their concerns and interests are competently expressed and protected (53 ${ }^{\text {rd }}$ Commonwealth parliamentary conference, 2007 ).

\subsection{To offer a viable alternative to the government}

The opposition also develops alternative policies and programs and presents itself as a viable alternative to the incumbent government $\left(53^{\text {rd }}\right.$ Commonwealth parliamentary conference, 2007). In a democratic set up, there is a constant reminder to the voters that there is a credible alternative to the government of the day. An alternative that has the potential to improve the quality of life of the people, serve their interests and let them realize their aspirations. The opposition presents a viable, alternative, ideological program and shows that it is more competent, to rule, than the ruling party (Bagbin et al., 2015). To attain democratization, only advocating democratization is not enough rather the opposition should serve as a credible alternative to the serving government as it is not possible to achieve and sustain democracy in the absence of alternative power. Stronger the opposition, brighter would be the future of democracy (Wing-yat \& Ka-man, 2012).

\subsection{Seeking accountability of government}

The opposition scrutinizes activities of the government by making the latter to justify its move. The opposition always remains active and vigilant and serves as a watchdog. It keeps the government within the prescribed limits of law by pointing out her shortcomings. It does not lose sight of its aims and objectives, which is to keep the government on the track. Thus, opposition ensures transparency in state affairs. ${ }^{6}$ The opposition also keeps check on the activities of the incumbent government by asking questions in the parliament and in different committees. Opposition members who are also members of different parliamentary committees usually call on and ask the government to account for the performance of its duties. Thus, the opposition has the opportunity to not only highlight but also expose those aspects of the 
government that do not serve common/national interests. Resultantly, the government of the day is induced to rethink and bring modifications in its policies and programs by bringing them in harmony with the common good $\left(53^{\text {rd }}\right.$ Commonwealth parliamentary conference, 2007).

\subsection{To oppose the government in power}

Opposition derives its status from the role of being opposing all the time. This role of the opposition to oppose the government is both vague and beneficial at the same time. Their ultimate goal is to convince the people to throw away the incompetent government and allow or facilitate the opposition to come into power and serve the masses in a better way. To achieve the purpose, the opposition parties highlight and exposes those aspects of the serving government, which, it believes, are contrary to the national interests. The opposition exposes the dark side (Bagbin et al., 2015), which the government attempts to put out of public sight i.e., unconstructive aspect. This is a fundamental responsibility of opposition to shield and protect the masses and society from the undemocratic acts and policies of the government in office. Performing this responsibility is not easy, because it attempts to confront and challenge each and every misuse of executive authority, violation of individual rights, waste of public money, and exposes all these for control. This is really a watchdog job and serves as a check over the unrestrained exercise of authority by the executive. It is through the performance of this role that the negative perception of the opposition arises (Bagbin et al., 2015). The opposition has the right to criticize the policies of the government, but it has to be fair in its criticism. The opposition should put forward alternative proposals with supportive arguments (Bagbin et al., 2015). It is essential for the opposition to be cautious while criticizing the incumbent party in power as it may be in government in coming time and yet fail to put into practice what it was criticizing the government for $\left(53^{\text {rd }}\right.$ Commonwealth Parliamentary Conference, 2007).

\subsection{In case of national tragedy and national glory}

It is the primary responsibility of not only the incumbent government but of the opposition as well to uphold and defend the sovereignty and territorial integrity of the state. Both must make every possible effort to ensure stability of the country and avoid such activities that are detrimental to the unity of the state (Bagbin et al., 2015). In the same way, if there occurs some national tragedy or mishap, they have to ignore and to put aside all their differences with each other and make collectively efforts to deal with the tragedy. Likewise, they also have to celebrate jointly when it is a matter of national pride and glory (Bagbin et al., 2015). It is in the interest of not only the democratic practice but also in the interest of the nation that both the incumbent and the opposition parties are loyal to the nation and uphold the rule of law regardless of the fact that they are critical of each other $\left(53{ }^{\text {rd }}\right.$ Commonwealth parliamentary conference, 2007).

\section{Why opposition is neglected in democracies}

In the $20^{\text {th }}$ century, the entire world saw a great transition in the human political history. Various newly independent states adopted democratic political systems. The world witnessed the fall of mighty empires like Ottoman, British and Austro-Hungarian. The century also saw the rise and fall of Fascism and Nazism, which were single party regimes. Communism competed the Western democracy and its existence was questioned after the disintegration of 
USSR in the late $20^{\text {th }}$ century by writing an influential thesis entitled "The End of History". According to Amartya Sen argues in seminal work "Democracy as a Universal Value" (1999) that, "throughout the nineteenth century, theorists of democracy found it quite natural to discuss whether one country or another was "fit for democracy." This thinking changed only in the twentieth century, with the recognition that the question itself was wrong: A country does not have to be deemed fit for democracy; rather, it has to become fit through democracy". Means that democracies tolerate dissent and through opposition, the ruling party policies could be checked. He added further, "this is indeed a momentous change, extending the potential reach of democracy to cover billions of people, with their varying histories and cultures and disparate levels of affluence". Besides political opposition, democracies need free press and media. Socialization and politicization of various issues and problems need free speech and free press. However, in the modern times censorship on political opposition and in media are common in both developed and developing countries. These states in the name of "public interest" interest not just censure political opposition but also impose restriction on freedom of speech wither expressed through art, literature or any other kind.

\section{Conclusion}

In a true democratic set-up, opposition is as important as the government, and it has to perform its role fearlessly and effectively. For performing such a role, the opposition has to be recognized, it should be accorded rights and it should be provided with such an environment to fulfill its democratic obligations and to act responsibly. In case of extreme confrontation between the ruling and opposition parties, if the incumbent government is all-powerful and wants to muzzle the opposition then opposition has to go for mass movement and agitation. This is then the only option available to opposition to save the democracy. The great Greek philosopher Plato has rightly put when he said that "the punishment of wise man who refuses to take part in the affairs of the government, is to live under the government of unwise men" (Kumari, n.d.). It is for the incumbent government to allow the opposition to fulfill these functions, which indicate a sign of democratic maturity on the part of the government. The opposition has to focus on its democratic functions and if it fails to do so, it will be a sign of dysfunctional democracy.

\section{References}

Akhtar, N. (2013). Role of political parties in the democratic system of Pakistan. https://gupea.ub.gu.se/handle/2077/33025

Bagbin, A. Ghana, Bagbin, H. A. S. K. (2015). The Role, Rights and Responsibilities of the Opposition. https://stephendieseruvwe.wordpress.com/2015/05/27/the-role-rightsand-responsibilities-of-the-opposition-by-hon-alban-s-k-bagbin/

European conference of presidents of parliaments, Oslo, Norway, 11-12 September 2014, p. 2 European conference of presidents of parliaments, Oslo, Norway, 11-12 September 2014, p. 2. Kamila, H. (2021, January 7). Dying dissent. The News. https://www.thenews.com.pk/print/770474-dying-dissent

Kiiza, J. (2005, August). The role of opposition parties in a democracy. In Regional Conference on Political Parties and Democratisation in East Africa, Tanzania. http://www.kasyp.net/fileadmin/kasyp_files/Documents/reused/PP the-role-ofopposition-parties-in-a-democracy _1_.pdf 
Kumari. S. (n.d.) What is the role of the opposition in a democracy: An essay. https://www.publishyourarticles.net/knowledge-hub/essay/what-is-the-role-ofopposition-in-democracy/5092/

Ozair, M., \& Khan, I. (2017). Federalism in Pakistan: The Question of Provincial Autonomy in Khyber-Pakhtunkhwa and Balochistan in the Post 18th Amendment Era. Iqbal International Institute for Research and Dialogue, International Islamic University.

Przeworski, A., Stokes, S. C. \& Manin, B. (1999). Democracy, accountability and representation. Cambridge University. http://assets.cambridge.org/97805216/41531/frontmatter/9780521641531_frontmatt er.pdf

Schapiro, L. (1967). 'Putting the lid on Leninism': Opposition and dissent in the communist one-party states. Government and opposition, 2(2), 181-203. https://www.cambridge.org/core/journals/government-andopposition/article/abs/putting-the-lid-onleninism/E66E10C17A6A348299D11B105D976E1E

Teshome, W. (2009). Opposition parties and the politics of opposition in Africa: A critical analysis. International Journal of Humanities and Social Sciences, 3(1), 1-15. https://citeseerx.ist.psu.edu/viewdoc/download?doi=10.1.1.308.4796\&rep=rep1\&ty pe=pdf

The Council of Europe Parliamentary Assembly. Resolution 1601 (2008). Procedural Guidelines on the Rights and Responsibilities of the Opposition in a Democratic Parliament.

Wing-yat, E. Y., \& Ka-man, N. C. (2012). The Political Opposition and Democracy in Macao: Revolutionaries or Loyalists? 1. Government and Opposition,47(1), 97-116. https://doi.org/10.1111/j.1477-7053.2011.01356.x

$53^{\text {rd }}$ Commonwealth Parliamentary Conference. (2007, September 27). Role, rights and responsibilities of the opposition, New Delhi, India, The Parliamentarian 2007/Issue Four 307.

\section{Notes}

${ }^{1}$ siteresources.worldbank.org/PSGLP/Resources/commonwealthunit7.pdf

2 http://www.preservearticles.com/201103254718/role-of-an-effective-opposition-in-a-democracy.html 24-10$\underline{2013}$

${ }^{3}$ The Council of Europe Parliamentary Assembly. Resolution 1601 (2008). Procedural Guidelines on the Rights and Responsibilities of the Opposition in a Democratic Parliament. http://assembly.coe.int/nw/xml/XRef/X2H-Xref-ViewPDF.asp?FileID=17626\&lang=en

${ }^{4}$ Such as the committee on finance, committee supervising security and intelligence services or the committee on audit.

${ }^{5} \mathrm{FAQs}$ regarding PAC on http://www.na.gov.pk/demo/?q=faqs.

${ }^{6}$ Commentary: The Role of the Opposition in a Democracy. http://dominicanewsonline.com/news/homepage/features/commentary/commentary-the-role-of-theopposition-in-a-democracy/ 